\title{
A INAUGURAÇÃO DO ANFITEATRO ARCADAS
}

\author{
Antonio Augusto Machado de Campos Neto
}

Chefe do Serviço Técnico de Imprensa

Dos telhados do prédio de apoio entre o andar correspondente ao quarto intermediário e o primeiro andar, realiza-se construção engenhosa e surge um espaço cultural que se passa a chamar Auditório Arcadas.

A inauguração foi realizada no dia 19 de abril de 2001, às 18 h00, e o novo auditório com instalação técnica e acústica de primeiro mundo está definitivamente pronto para conferências, seminários e palestras.

A șua localização é exatamente à Rua Riachuelo, $185,4^{\circ}$ Intermediário, comporta em sua construção ultramoderna cerca de sessenta lugares e é saldo de importante e representativa contribuição do Banco Brasileiro de Descontos (Bradesco) a esta Unidade da USP.

Cumpre salientar que o novo auditório foi totalmente financiado pelo Bradesco que, mais uma vez, vem contemplar as expectativas dos corpos docente e discente desta Faculdade de Direito. São iniciativas que faz com que a Faculdade haja em seu expediente, através de implementação e expansão na realização de cursos institucionais e dirigidos que venham aprofundar os conhecimentos de alunos de graduação e pós-graduação.

O Auditório Arcadas é propício a essa organização de cursos, inclusive os de especialização de curtíssima duração, a exemplo dos ministrados em outros países, com ênfase aos da Itália, França, Alemanha e Inglaterrạ.

E a Faculdade nos seus 172 anos de plena existência, quando se aborda o sistema do ensino jurídico no País é de suma importância; é uma liderança mantida em virada de século, uma vez estarmos no ano 2001.

O novo Auditório Arcadas vem inteirar as glórias da Faculdade que somente é admitida aos que a amam e a proclamam no cotidiano, no sempre e no futuro.

$\mathrm{Na}$ inauguração, presentes: a senhora diretora, professora doutora Ivette

Senise Ferreira, o ex-diretor da Faculdade, professor doutor Álvaro Villaça Azevedo, o Sr. Luiz Carlos Trabucco Cappi, vice-presidente do Bradesco; Milton Matsumoto, 
diretor-gerente do Bradesco; Carlos Alberto Rodrigues Guilherme, diretor-gerente do Bradesco; representantes do Centro Acadêmico XI de Agosto e Departamento Jurídico XI de Agosto, da Associação dos Antigos Alunos, professores e funcionários da Faculdade de Direito, que após a cerimônia, participaram do coquetel de inauguração.

São Paulo, maio de 2001. 